(2) Open Access Full Text Article

ORIGINAL RESEARCH

\title{
Design, synthesis and evaluation of VEGF-siRNA/ CRS as a novel vector for gene delivery
}

This article was published in the following Dove Press journal:

Drug Design, Development and Therapy

24 November 2016

Number of times this article has been viewed

\section{Wen Zhao \\ Yifan Zhang \\ Xueyun Jiang \\ Chunying Cui}

School of Chemical Biology and Pharmaceutical Sciences, Capital Medical University, Beijing, China

Correspondence: Chunying Cui School of Chemical Biology and Pharmaceutical Sciences, Capital Medical University, Number 10 Xitoutiao, Youanmenwai, Beijing 100069, China

Tel $+86108391 \quad 1668$

Fax +861083911533

Email ccy@ccmu.edu.cn
Abstract: Small interfering RNA (siRNA) delivery is a prospective method in gene therapy, but it has application limitations such as negative charge, water solubility and high molecular weight. In this study, a safe and efficient nano-vector, CRS, was designed and synthesized to facilitate siRNA delivery. Physical and chemical properties of VEGF-siRNA/CRS were characterized by methods including scanning electron microscopy (SEM), transmission electron microscopy, zeta potential ( $\zeta$ ) measurement, drug-releasing rate measurement, gel electrophoresis and confocal microscopy. The biological activities were evaluated using cell viability assay, gene-silencing efficacy assay in vitro, real-time polymerase chain reaction, enzyme-linked immunosorbent assay (ELISA) and antitumor tests in vivo. The mean nanoparticle size of VEGF-siRNA/CRS was $121.4 \pm 0.3 \mathrm{~nm}$ with positive $\zeta$ potential of $7.69 \pm 4.47 \mathrm{mV}$. The release rate of VEGF-siRNA from VEGF-siRNA/CRS was $82.50 \%$ sustained for $48 \mathrm{~h}$ in Tris-ethylenediaminetetraacetic acid buffer ( $\mathrm{pH} 8.0$ ). Real-time polymerase chain reaction was used to analyze the efficiency of the transfection, and the result showed that VEGF mRNA expression had been knocked down by $82.36 \%$. The expression of VEGF protein was also recorded to be downregulated to $14.83 \%$ using ELISA. The results of cytotoxicity measured by Cell Counting Kit- 8 assay showed that VEGF-siRNA/CRS had significant inhibitory effect on HeLa cells. The results of antitumor assays indicated that VEGF-siRNA/CRS exhibited tumor cell growth inhibition in vivo. The results demonstrated that VEGF-siRNA could be delivered and transported by the designed carrier, while siRNA could be released constantly and led to an increasing gene-silencing effect against VEGF gene. In conclusion, VEGF-siRNA/CRS is a promising carrier for siRNA delivery, and further studies are warranted.

Keywords: CRS, siRNA delivery, VEGF, tumor therapy, antitumor, biophysical characteristics, gene silencing, protein expression

\section{Introduction}

RNA interference is the sequence-specific, post-transcriptional gene-silencing phenomenon initiated by small interfering RNA (siRNA). It can block tumor-type specific genes such as VEGF and survivin, which are required for tumor growth. ${ }^{1,2}$ The clinical application of siRNA is limited because of its low delivery efficiency and transfection rate, which is due to its large molecular size, water solubility, negatively charged surface and rapid degradation in serum. ${ }^{3,4}$ A newly designed carrier system of siRNA is required to overcome these problems. ${ }^{5}$ Many carriers have been modified and studied for siRNA delivery, and they include viral, nanoparticle, nanogel, protein and peptide carriers (or vectors). ${ }^{6}$ Viral vectors are efficient, but they have high immunogenicity and high cytotoxicity in vivo, which make them less convenient in clinical treatment. ${ }^{7}$ Therefore, several efforts and studies have been focused on the development of non-viral carriers..$^{3,8,9}$ 
The DNA-intercalating compound $\beta$-carboline alkaloid has been synthesized from natural amino acid through condensation reaction, and among all synthesized DNA intercalators, ${ }^{10,11} \beta$-carboline alkaloid is widely used in drug delivery systems and as a DNA intercalation agent. ${ }^{12,13}$ In a previous study, ${ }^{12} \beta$-carboline derivates were proved to intercalate into DNA double helix and cause DNA damage and inhibit the growth of tumor significantly. Meanwhile, they were shown to be biocompatible, non-inflammatory, nontoxic and biodegradable for drug delivery. ${ }^{5}$ However, there remains a need for these newly synthesized tumor-targeted siRNA delivery carriers to be explored. ${ }^{14}$

In this study, $1-\mathrm{CH}_{3}-\beta$-carboline-3-COOH was synthesized, and its 3-COOH group was linked with RGDS (Arg-Gly-Asp-Ser) peptide, which can target the tumor cells. RGD motif is one of the transmembrane glycoproteins; it acts as a mediator in cell adhesion by linking to intergrin..$^{15,16}$ RGDS peptide can bind to integrin receptors with high affinity, inhibit cell adhesion and result in anti-inflammatory, anti-angiogenesis and anti-migration activities. ${ }^{17}$ At present, hydrophilic RGDS peptide is widely used as a carrier precursor and pharmacophore in the modification procedures of antitumor drugs, since it can target the tumor cells and has a low clearance rate in vivo. ${ }^{18}$ In this study, VEGF-siRNA/CRS was designed and synthesized as a new siRNA delivery vector, and it was demonstrated that VEGF-siRNA could be delivered into HeLa cells to induce significant gene-silencing effects and to regulate the related protein expression at the cellular level. The physical and chemical parameters were evaluated, and the morphological features and gene transfection efficiency were characterized against HeLa cell line in vitro. The genesilencing efficiency was evaluated by real-time polymerase chain reaction (RT-PCR), and the protein expression was detected by enzyme-linked immunosorbent assay (ELISA). The cytotoxicity of the vector was measured by Cell Counting Kit-8 (CCK-8) assay, and the targeting efficiency and tumor cell viability were evaluated in vivo. The purpose of this study was to demonstrate the feasibility of 1-methyl- $\beta$-caboline-3RGDS to be a promising delivery system for siRNA.

\section{Materials and methods}

All human tissue and cell work was performed according to the Health Guidelines of Capital Medical University, and the study protocols were approved by the Institutional Animal Ethics Committee of Capital Medical University.

\section{Instruments and materials}

Tetrahydrofuran, dimethylformamide, dicyclohexylcarbodiimide, 1-hydroxybenzotriazole and $N$-methylmorpholine were purchased from Sigma-Aldrich Co. (St Louis, MO, USA). L-Trp, Boc-Arg (Tos), Boc-Asp (OBzl), HCl-Gly-OBzl and $\mathrm{HCl} \cdot$ Ser-OBzl were purchased from Biochem Ltd (Shanghai, China). HeLa cell lines were obtained from the Institute of Basic Medical Sciences Chinese Academy of Medical Sciences (Beijing, China). VEGF-siRNA, negative control (NC), fluorescein-labeled siRNA (Cy3/FAM-siRNA), VEGF primers (forward sequence: 5'-ATCGAGACCCTGGTGGACA-3', reverse sequence: 5'-CCGCCTCGGCTTGTCACA-3') and glyceraldehyde 3-phosphate dehydrogenase (GAPDH) primers (forward sequence: 5'-CAAATTCCATGGCACCGTCA-3', reverse sequence: $5^{\prime}$-GGAGTGGGTGTCGCTGTTGA-3') were synthesized and purified by GenePharma Co., Ltd. (Shanghai, China). Dulbecco's Modified Eagle's Medium (DMEM), fetal bovine serum, penicillin, streptomycin and trypsin were purchased from HyClone Laboratories Inc. (Logan, UT, USA). CCK-8 was purchased from Dojindo Molecular Technologies (Osaka, Japan). Butyleyanoacrylate protein kit was purchased from Pierce (Rockford, IL, USA). Cy3 marker was purchased from AAT Bioquest Inc. (Sunnyvale, CA, USA). To-Pro ${ }^{\circledR}-3$ Iodide $(642 / 661)$, diethylpyrocarbonate (DEPC) water, Lipofectamine ${ }^{\mathrm{TM}} 2000$, TRIzol reagent, VEGF ELISA Kit, RNA to CDNA and TaqMan Mix were purchased from Thermo Fisher Scientific (Waltham, MA, USA). All reagents were of chemical grade unless otherwise specified. S180 cells were obtained from Vital River Laboratory Animal Technology Co., Ltd. (Beijing, China).

Kodak Gel Logic 200 Imaging System (Eastman Kodak Company, Rochester, NY, USA), ZetaPlus zeta potential instrument (Brookhaven Instruments Corporation, Holtsville, NY, USA), Hitachi S-4800 (Hitachi Ltd., Tokyo, Japan), transmission electron microscopy (TEM; JEOL, Tokyo, Japan), dialysis tube (molecular weight [MW] 8,000-14,000 Da; Thermo Fisher Scientific), Copper grid (Zhongjingkeyi Technology Co., Ltd, Beijing, China), Victor X5 plate reader (PerkinElmer Inc., Waltham, MA, USA), Real-Time PCR System (model 7500; Thermo Fisher Scientific), confocal laser scanning microscopy (Leica Microsystems, Wetzlar, Germany), 7T-MRI scanner (Bruker Corporation, Billerica, MA, USA), Kodak FX Pro (Kodak Alaris Inc., Tokyo, Japan), Malvern Zetasizer NanoZS900 (Malvern Instruments, Malvern, UK) and confocal microscope (Leica Microsystems) were used in this study.

\section{Synthesis of I-methyl- $\beta$-caboline-3- carboxylic acid}

Following the previous work, ${ }^{19} 1$-methyl- $\beta$-caboline-3carboxylic acid was synthesized using a four-step method 


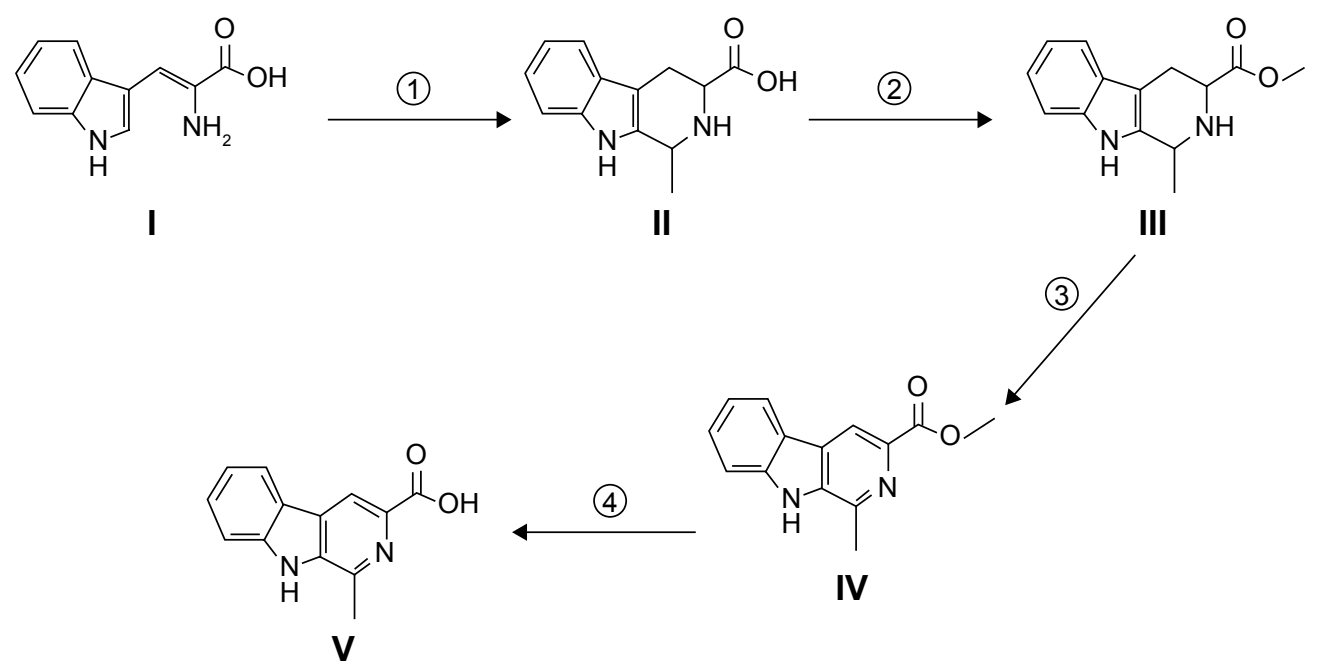

Scheme I Synthesis of I-methyl- $\beta$-caboline-3-carboxylic acid.

Notes: Steps: (1), $\mathrm{CH}_{3} \mathrm{CHO} / \mathrm{H}^{+}$; (2), $\mathrm{SOCl} / \mathrm{CH}_{3} \mathrm{OH}$; (3), $\mathrm{KMnO}_{4} / \mathrm{CH}_{3} \mathrm{COCH}_{3}$ and (4), $\mathrm{NaOH}$. By the Pictet-Spengler reaction, I-Trp (I) was initially turned into (IS,3S)-Imethyl-I,2,3,4-tetrahydro- $\beta$-carboline-3-carboxylic acid (II) by condensation with $\mathrm{CH}_{3} \mathrm{CHO} / \mathrm{H}^{+}$, and compound II was esterified into (IS,3S)-I-methyl-I,2,3,4-tetrahydro$\beta$-carboline-3-carboxylic acid methyl ester (III). The oxidation reaction of compound III was catalyzed by $\mathrm{KMnO}_{4}$, and (IS,3S)-I-methyl- $\beta$-carboline-3-carboxylic acid methyl ester (IV) was synthesized. Compound IV was saponified into I-methyl- $\beta$-caboline-3-carboxylic acid (V).

depicted in Scheme 1. By the Pictet-Spengler reaction, L-Trp (I) was initially turned into (1S,3S)-1-methyl1,2,3,4-tetrahydro- $\beta$-carboline-3-carboxylic acid (II) by condensation with $\mathrm{CH}_{3} \mathrm{CHO} / \mathrm{H}^{+}$, and compound II was esterified into (1S,3S)-1-methyl-1,2,3,4-tetrahydro- $\beta$ carboline-3-carboxylic acid methyl ester (III). The oxidation reaction of compound III was catalyzed by $\mathrm{KMnO}_{4}$, and (1S,3S)-1-methyl- $\beta$-carboline-3-carboxylic acid methyl ester (IV) was synthesized. Compound IV was saponified into 1-methyl- $\beta$-caboline-3-carboxylic acid $(\mathbf{V})$.

\section{Synthesis of RGDS peptide}

Following our previous work, ${ }^{20,21}$ RGDS was synthesized using liquid-phase peptide synthesis according to Scheme 2 . Boc-Arg(Tos) and Boc-Asp(OBzl) were first linked with $\mathrm{HCl} \cdot \mathrm{Gly}-\mathrm{OBzl}$ and $\mathrm{HCl} \cdot \mathrm{Ser}-\mathrm{OBzl}$, respectively, and then the OBzl group of Boc-Arg(Tos)-Gly-OBzl and the Boc group of Boc-Asp(OBzl)-Ser-OBzl were removed by hydrogenesis and acidolysis. Boc-Arg(Tos)-Gly-Asp(OBzl)-Ser-OBzl was obtained by linking Boc-Arg(Tos)-Gly and $\mathrm{HCl} \cdot \mathrm{Asp}(\mathrm{OBzl})-$ Ser-OBzl together.

\section{Synthesis of I-methyl- $\beta$-caboline-3-RGDS}

Following the method in Scheme 1, compound $\mathbf{V}$ was turned to 1-methyl- $\beta$-caboline-3-RGDS (VI) by linking with $\mathrm{HCl} \cdot \mathrm{Arg}(\mathrm{Tos})-\mathrm{Gly}-\mathrm{Asp}(\mathrm{OBzl})-\mathrm{Ser}-\mathrm{OBzl}$. The 1-methyl- $\beta$ caboline-3-RGDS with carboxyl and amino terminal (VII) precipitated out during acidolysis (Scheme 3).

The structure and purity of CRS were elucidated and evaluated with ${ }^{1} \mathrm{H}$ nuclear magnetic resonance (NMR), 13C NMR, mass spectra, infrared (IR) spectrum, ultraviolet (UV) spectrum and high-performance liquid chromatography (HPLC).

\section{Synthesis of CRS}

Orthogonal screening tests were carried out, including lecithin $(\mathrm{PC}), \mathrm{CRS}(\mathrm{m} / \mathrm{m}), \mathrm{PC}+\mathrm{CRS}$, cholesterol $(\mathrm{CH})(\mathrm{m} / \mathrm{m})$ and surfactant $(\mathrm{m} / \mathrm{v})$. Lipid mixtures, including cholesterol, lecithin and $\mathrm{CRS}$, were dissolved in $\mathrm{CH}_{3} \mathrm{OH}$ and $\mathrm{CHCl}_{3}$, and the solvent was evaporated to leave the residue film in vacuum overnight. ${ }^{22}$ After removing all the organic solvents, the residue film was rinsed with RNase-free water. The CRS was hydrated, sonicated and saved for further use.

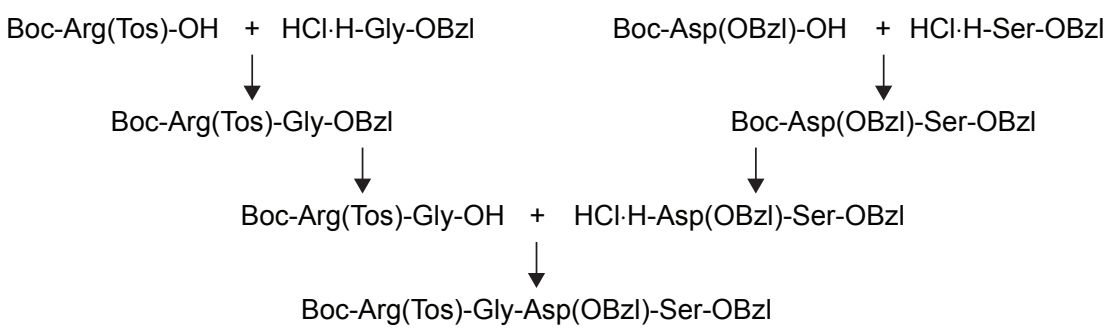

Scheme 2 Synthesis of RGDS peptide. 


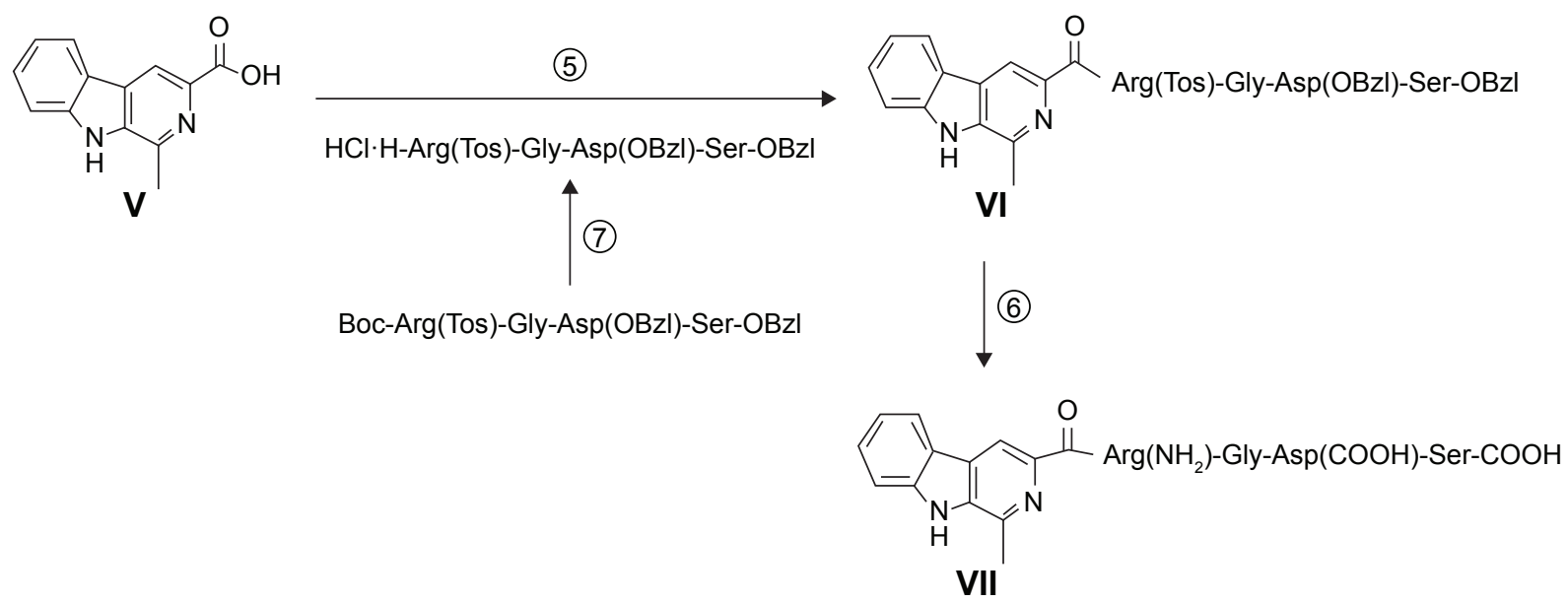

Scheme 3 Synthesis of I-methyl- $\beta$-caboline-3-RGDS with carboxyl and amino terminal.

Notes: Steps: (5), DCC/HOBt/NMM; (6), TFA/TfOH and (7), HCl-EtOAc. Following the method in Scheme I (steps I-4), compound V was turned to I-methyl- $\beta$-caboline3-RGDS (VI) by linking with $\mathrm{HCl} \cdot \mathrm{Arg}(\mathrm{Tos})$-Gly-Asp(OBzl)-Ser-OBzl. The I-methyl- $\beta$-caboline-3-RGDS with carboxyl and amino terminal (VII) precipitated out during acidolysis.

Abbreviations: DCC, dicyclohexylcarbodiimide; HOBt, I-hydroxybenzotriazole; NMM, N-methylmorpholine; TFA, trifluoroacetic acid; TfOH, trifluoromethanesulfonic acid; EtOAc, ethyl acetate.

\section{Preparation for gel electrophoresis of VEGF-siRNA/CRS}

VEGF-siRNA was added into CRS and incubated with protamine at $24^{\circ} \mathrm{C}$ for $20 \mathrm{~min}$. According to the method in the "Synthesis of CRS" section, VEGF-siRNA was incubated with 25\% CRS (75\% PC), 50\% CRS (50\% PC), 75\% CRS (25\% PC) and 100\% CRS. Blank and naked siRNA were added as controls. Agarose gel (1\%) containing $0.5 \mu \mathrm{g} / \mathrm{mL}$ of ethidium bromide in Tris-borate buffer was prepared. All test candidates were mixed with $4 \mu \mathrm{L}$ of six times of loading dye. The electrophoresis was carried out at $95 \mathrm{~V}$ for $30 \mathrm{~min}$, the gel was observed under UV light and the results were recorded using Kodak Gel Logic 200 Imaging System. The experiments were repeated three times.

\section{Particle size and $\zeta$ potential in} characterization of the VEGF-siRNA/CRS

The particle size and $\zeta$ potential of the control, CRS and VEGF-siRNA/CRS were evaluated on a $\zeta$ potential meter at room temperature. All samples were diluted with DEPC water 20 times, and the experiments were repeated individually three times. ${ }^{18}$

\section{Scanning electron microscopy (SEM) and TEM}

The nano-image of VEGF-siRNA/CRS was obtained by SEM. All samples were diluted 40 times and dripped onto a $10 \mathrm{~mm}$ slide for observation.

The morphology studies of VEGF-siRNA/CRS were carried out with TEM. All samples were diluted 40 times with DEPC water. In all, $0.25 \mu \mathrm{L}$ of VEGF-siRNA/CRS was diluted with $10 \mu \mathrm{L}$ of water and dripped onto a copper grid, and then a drop of a hydrous ethanol was added to remove the water. The grid was first dried thoroughly in the air and then heated at $35^{\circ} \mathrm{C}$ for 4 days to be absolutely anhydrous for the test. The TEM was operated at $80 \mathrm{kV}$, and images were recorded using Gatan Bioscan Camera 1792 (Pleasanton, CA, USA) and magnified 6,000-400,000 times digitally.

\section{Faraday-Tyndall}

Laser light (650 nm) was used to visualize the nano-property and Faraday-Tyndall effect of CRS in solution. In all, $25 \%, 50 \%, 75 \%$ and $100 \%$ of CRS in ultrapure water were used as test candidates. Ultrapure water was used as blank control. All samples were diluted 20 times with DEPC water in a penicillin vial, and the Faraday-Tyndall effects were compared.

\section{Release of CRS and VEGF-siRNA from VEGF-siRNA/CRS in vitro}

The in vitro release of CRS was confirmed by dialysis; $266.3 \mu \mathrm{L}$ of VEGF-siRNA/CRS was added in the dialysis tube (MW 8,000-14,000 Da). The tube was immersed in $1.5 \mathrm{~mL}$ of $40 \%$ methanol in phosphate-buffered saline (PBS) solution and shaken at 150 times/min in the water bath at $37^{\circ} \mathrm{C}$. The results were collected at $0,2,4,6,12,24$ and $48 \mathrm{~h}$. At the given times, the solvent was completely removed and replaced with fresh PBS solution. The amount of released CRS was measured by UV spectrometer at the wavelength of 
$271 \mathrm{~nm}$. Release of VEGF-siRNA from VEGF-siRNA/CRS was performed, but the solvent was replaced with $1.5 \mathrm{~mL}$ of Tris-ethylenediaminetetraacetic acid buffer $(10 \mathrm{mM}$ Tris$\mathrm{HCl}$ and $1 \mathrm{mM}$ ethylenediaminetetraacetic acid, $\mathrm{pH}$ 8.0). Release of VEGF-siRNA was measured by a fluorescent plate reader. Excitation wavelength was set at $492 \mathrm{~nm}$, and emission wavelength was set at $520 \mathrm{~nm}$. All experiments were repeated five times.

\section{Cytotoxicity assay}

The viability of tumor cells was evaluated by CCK- 8 assay against a HeLa cell line. ${ }^{23} \mathrm{HeLa}$ cells were cultured for four generations, and $3 \times 10^{3}$ cells were seeded in 96-well plates and incubated for $24 \mathrm{~h}$. After washing with PBS three times, naked VEGF-siRNA, VEGF-siRNA/Lipofectamine 2000, NC/CRS and VEGF-siRNA/CRS (25\%, 50\%, 75\% and $100 \%$ ) were diluted with fresh medium and were added into 96-well plates. The concentrations of VEGF-siRNA were $25 \mathrm{nM}, 50 \mathrm{nM}, 75 \mathrm{nM}, 100 \mathrm{nM}$ and $125 \mathrm{nM}$, and the medium was replaced with complete DMEM. The naked VEGF-siRNA was used as the NC, and the Lipofectamine 2000 was used as the positive control. After 48 h, CCK-8 was added at the concentration of $10 \mu \mathrm{L} /$ well and incubated for another $4 \mathrm{~h}$. The absorbance was measured at the detection wavelength of $450 \mathrm{~nm}$ using Victor X5 plate reader. The cell viability was calculated according to the following equation:

$$
\text { Cell viability }=\frac{A_{\text {Sample }}-A_{\text {Blank }}}{A_{\text {Control }}-A_{\text {Blank }}} \times 100 \%
$$

All experiments were repeated six times.

\section{Enzyme-linked immunosorbent assay}

Downregulation of VEGF protein expression was analyzed by ELISA. The fourth-generation HeLa cells $\left(1 \times 10^{5} / \mathrm{mL}\right)$ were seeded in 24 -well plates $(0.5 \mathrm{~mL} /$ well $)$; washed with PBS solution three times; transfected with fresh medium containing DEPC water, VEGF-siRNA, NC/CRS, VEGFsiRNA/Lipofectamine 2000 and VEGF-siRNA/CRS and incubated at $37^{\circ} \mathrm{C}$ for $4 \mathrm{~h}$. The concentrations of VEGFsiRNA/CRS were $50 \mathrm{nM}, 75 \mathrm{nM}, 100 \mathrm{nM}$ and $125 \mathrm{nM}$, and the medium was replaced with complete DMEM. All cells were incubated for $48 \mathrm{~h}$, and the supernatants were collected. The amount of VEGF protein was measured by ELISA, and the absorbance was recorded at the detection wavelength of $450 \mathrm{~nm}$ using Victor X5 plate reader.

\section{Analysis of gene-silencing activity by real-time PCR}

The decrease in VEGF-mRNA expression in HeLa cells was evaluated by RT-PCR assay. ${ }^{24}$ Fourth-generation HeLa cells $\left(3 \times 10^{5} / \mathrm{mL}\right)$ were seeded in six-well plates $(1 \mathrm{~mL} /$ well $)$; washed with PBS solution three times; transfected with fresh medium containing VEGF-siRNA, NC/CRS, VEGF-siRNA/ Lipofectamine ${ }^{\text {TM }} 2000$ and VEGF-siRNA/CRS individually and incubated for $4 \mathrm{~h}$. Naked VEGF-siRNA was used as NC, and Lipofectamine ${ }^{\mathrm{TM}} 2000$ was used as positive control. The concentrations of VEGF-siRNA/CRS were $75 \mathrm{nM}, 100 \mathrm{nM}$ and $125 \mathrm{nM}$. The medium was replaced with complete DMEM and incubated for $>48 \mathrm{~h}$. The cells were washed three times with PBS, lysed in TRIzol reagent and VEGF-mRNA was isolated. RT-PCR was carried out, and GAPDH was used as the internal standard. The results were calculated using the delta-delta $\mathrm{Ct}\left(2^{-\Delta \Delta C_{\mathrm{t}}}\right)$ method. All experiments were repeated three times.

\section{Confocal microscopy}

In order to evaluate the transfection ability of VEGF-siRNA/ CRS, confocal laser scanning microscopy was used. ${ }^{25}$ Before transfection, $1 \times 10^{5} \mathrm{HeLa}$ cells/well were incubated for $24 \mathrm{~h}$ in $35 \mathrm{~mm}$ cell culture dishes. After the culture reached $70 \%-80 \%$ confluence, the cells were washed three times with PBS solution and incubated at $37^{\circ} \mathrm{C}$ with VEGFsiRNA/CRS for $2 \mathrm{~h}$ and $4 \mathrm{~h}$. All cells were then rinsed with iced PBS solution three times, fixed by $10 \%$ formaldehyde solution for $20 \mathrm{~min}$ and stained with $100 \mathrm{nM}$ To-Pro in PBS solution for $15 \mathrm{~min}$. The results of stained cells were collected and examined by confocal microscope (excitation wavelength at $548 \mathrm{~nm}$ and $642 \mathrm{~nm}$ and emission wavelength at $562 \mathrm{~nm}$ and $661 \mathrm{~nm}$ ) for Cy3-labeled siRNA group and To-Pro group, respectively.

\section{Tumor xenograft model in vivo tumor targeting and bio-distribution study}

Male Institute of Cancer Research (ICR) mice (6 weeks old, 18-22 g) were obtained from the Animal Department of Capital Medical University (Beijing Laboratory Animal Center, Beijing, China). All animal procedures were handled in accordance with the guidelines of Capital Medical University, and protocols were approved by the Institutional Animal Ethics Committee of Capital Medical University. Tumor xenograft was made by hypodermic injection of S180 cells. Animal magnetic resonance imaging (MRI) experiments were performed on the 7T-MRI scanner. The full-body scan and local scan at the right armpit were recorded. Rapid 
acquisition with relaxation enhancement sequence images was recorded and analyzed.

\section{In vivo target distribution of CRS}

To confirm the target distribution of CRS modified by RGDS, images of mice were taken by the image system FX Pro. CRS was incubated with Cy3 in DEPC water for 10 min, which was used as a test candidate. Naked $\mathrm{Cy} 3$ was used as control. The drugs were injected into male ICR mice (6 weeks old, 18-22 g), and fluorescence animal sagittal images were recorded at the times of $15 \mathrm{~min}, 30 \mathrm{~min}, 60 \mathrm{~min}, 120 \mathrm{~min}$ and $240 \mathrm{~min}$. The parallel experiments were carried out ten times.

\section{Inhibition of tumor growth}

Tumor xenograft was made by inoculating $1 \times 10^{7} \mathrm{~S} 180$ cells into ICR mice. Tumor in each mouse was measured using vernier caliper. After 7 days, the mean volume of tumor reached $80-90 \mathrm{~mm}^{3}$. Mice were divided into four groups $(n=10)$. VEGF-siRNA/CRS and naked VEGF-siRNA (100 nM) were intravenously injected into 2 groups for 5 days. CRS and doxorubicin (DOX; $20 \mu \mathrm{mol} / \mathrm{kg}$ ) were used as blank control and positive control, respectively. After the last injection, tumors were harvested and compared.

\section{Data processing}

The results are shown as mean \pm standard deviation and calculated from at least three independent experiments. Statistical analysis was carried out by paired $t$-test. A $P$-value $<0.05$ was considered to be statistically significant, and a $P$-value $<0.01$ indicated high significance.

\section{Results and discussion Synthesis}

The structure of 1-methyl- $\beta$-caboline-3-RGDS with carboxyl and amino terminal was identified by ${ }^{1} \mathrm{H}$ NMR, $13 \mathrm{C}$ NMR, mass spectra and IR spectrum. In UV spectrum, the maximum absorption was observed at wavelength $271.0 \mathrm{~nm}$. Purity of the final product reached $95.06 \%$, which was evaluated using HPLC. These findings proved the successful synthesis of CRS carrier.

\section{Formulation and characterization}

Nine orthogonal experiments (E1-E9) were carried out to test the interrelation between particle size and zeta potential against four candidates, A (PC:CRS, m/m), $\mathrm{B}(\mathrm{PC}+\mathrm{CRS}: \mathrm{CH}, \mathrm{m} / \mathrm{m}), \mathrm{C}$ (emulsifying agent, $\mathrm{m} / \mathrm{v}$ ) and $\mathrm{D}$ (probe ultrasound, $\mathrm{min}$ ), followed by the procedure of the Schafer's research. ${ }^{26}$ The results from L9 $\left(3^{4}\right)$ statistic experiments are listed in Table 1, and the results of orthogonal analysis are listed in Table 2 . The total score of the nine experiments is listed in Table 1 and was calculated using particle size $(\varepsilon=-1)$ and zeta potential $(\varepsilon=2)$. The scores were later converted into statistic factors $K$ (three levels) and $R$ to evaluate the total effect between each test candidate among three levels (Table 2). $\mathrm{E}_{1}-\mathrm{E}_{3}\left(K_{1}\right), \mathrm{E}_{4}-\mathrm{E}_{6}\left(K_{2}\right), \mathrm{E}_{7}-\mathrm{E}_{9}\left(K_{3}\right)$ were three levels used in this experiment, and $R$ was used for comprehensive comparison of three levels.

It can be observed from Table 2 that test groups of $\mathrm{A}, \mathrm{B}, \mathrm{C}$ and $\mathrm{D}$ show different influences on the preparation of CRS. In each column, the absolute values of A- $K_{3}$ $(-194.933), \mathrm{B}-K_{2}(-665.447), \mathrm{C}-K_{2}(-296.280)$ and $\mathrm{D}-K_{3}$ $(-171.407)$ are more close to zero, indicating that siRNA enwrapping was easier than for the other groups. The preparation conditions of the aforementioned group results were $\mathrm{A}(\mathrm{PC}: \mathrm{CRS}, \mathrm{m} / \mathrm{m})=0: 100, \mathrm{~B}((\mathrm{PC}+\mathrm{CRS}): \mathrm{CH}, \mathrm{m} / \mathrm{m})=10: 1$, $\mathrm{C}$ (emulsifying agent, $\mathrm{m} / \mathrm{v}$ ) $=10 \mathrm{mg} / \mathrm{mL}$ and $\mathrm{D}$ (probe ultrasound, $\min )=15 \min$.

\section{Gel electrophoresis of VEGF-siRNA/CRS}

Cationic carrier has been widely used in the siRNA delivery system, ${ }^{27}$ and the loading capacity of the carrier depends on its electric property. As shown in Figure 1, an electrophoretic mobility shift was used to evaluate the siRNA binding ability of CRS. The siRNA was shown as bright bands, and it could be absorbed by the CRS carrier; the conjugated siRNA was not observed.

Table I Formulation of CRS by L9 $\left(3^{4}\right)$ statistic experiment

\begin{tabular}{llllllll}
\hline Experiment & $\mathbf{A}(\mathbf{m g} / \mathbf{m g})$ & $\mathbf{B}(\mathbf{m g} / \mathbf{m g})$ & $\mathbf{C}(\mathbf{g} / \mathbf{l 0 0} \mathbf{~ m L})$ & $\mathbf{D}(\mathbf{m i n})$ & Particle size $(\mathbf{n m})$ & Zeta potential $(\mathbf{m V})$ & Score \\
\hline EI & $40: 60$ & $5: 1$ & 0 & 5 & $2,422.7$ & -32.87 & $-2,488.44$ \\
E2 & $40: 60$ & $10: 1$ & 1 & 10 & 467.9 & -27.71 & -523.32 \\
E3 & $40: 60$ & $15: 1$ & 2 & 15 & 103.3 & 0.29 & -102.72 \\
E4 & $30: 70$ & $5: 1$ & 1 & 15 & 127.8 & -17.46 & -162.72 \\
E5 & $30: 70$ & $10: 1$ & 2 & 5 & $1,204.1$ & -10.07 & $-1,244.23$ \\
E6 & $30: 70$ & $15: 1$ & 0 & 10 & $2,680.3$ & -4.06 & $-2,688.42$ \\
E7 & $0: 100$ & $5: 1$ & 2 & 10 & 122.9 & -5.16 & -133.22 \\
E8 & $0: 100$ & $10: 1$ & 0 & 15 & 320.8 & 36.01 & $-2,487.8$ \\
E9 & $0: 100$ & $15: 1$ & 1 & 5 & 216.1 & 6.65 & -202.8 \\
\hline
\end{tabular}

Notes: Values are expressed as mean \pm standard deviation $(n=3)$. L9 is the code of orthogonal experiment; There are four candidates: A (lecithin:CRS, m/m), B (lecithin + CRS:cholesterol, $\mathrm{m} / \mathrm{m}$ ), C (emulsifying agent, $\mathrm{m} / \mathrm{v}$ ) and $\mathrm{D}$ (probe ultrasound, $\mathrm{min}$ ). 
Table 2 Orthogonal analysis of $L 9\left(3^{4}\right)$ statistic experiment

\begin{tabular}{lllll}
\hline Parameter & A & B & C & D \\
\hline$K_{1}$ & $-1,380.161$ & -928.127 & $-1,808.547$ & $-1,305.160$ \\
$K_{2}$ & $-1,358.460$ & -665.447 & -296.280 & $-1,|1| 4.987$ \\
$K_{3}$ & -194.933 & -997.980 & -486.727 & $-|7| .407$ \\
$R$ & $1,163.527$ & 332.533 & $|, 5| 2.267$ & $\mathrm{I}, \mid 33.753$ \\
\hline
\end{tabular}

Notes: L9 is the code of orthogonal experiment; There are four candidates: A (lecithin:CRS, $\mathrm{m} / \mathrm{m}$ ), B (lecithin + CRS:cholesterol, $\mathrm{m} / \mathrm{m}$ ), C (emulsifying agent, $\mathrm{m} / \mathrm{v}$ ) and $D$ (probe ultrasound, min). $E_{1}-E_{3}\left(K_{1}\right), E_{4}-E_{6}\left(K_{2}\right), E_{7}-E_{9}\left(K_{3}\right)$ were three levels used in this experiment, and $R$ was used for comprehensive comparison of three levels.

From group A to D (Figure 1), different concentrations of CRS (A: 25\% CRS, B: 50\% CRS, C: $75 \%$ CRS, D: $100 \%$ CRS; see the "Synthesis of CRS" section for further details) were used. In each gel, one unit of siRNA was used as a substrate to evaluate the volume of CRS used. All the bright bands disappeared, indicating that the siRNA was successfully enwrapped by the CRS.

The results showed that the CRS-conjugated siRNA was inhibited from moving toward the positive electrode in agarose gel, and the group $0.83 \mathrm{pmol} / \mu \mathrm{L}$ (Figure 1A), $1.11 \mathrm{pmol} / \mu \mathrm{L}$ (Figure 1B), $1.28 \mathrm{pmol} / \mu \mathrm{L}$ (Figure 1C) and $1.33 \mathrm{pmol} / \mu \mathrm{L}$ (Figure 1D) were the best results in each gel. From $\mathrm{D}$ to $\mathrm{A}$, the siRNA bands faded more rapidly along with the increasing concentration of CRS, which indicated that siRNA was more easily loaded into the CRS. The results proved the successful entrapment of siRNA by CRS at different concentrations, and the formulation of VEGF-siRNA/ CRS (100\%) had the highest efficiency among all the test groups.

\section{Physiochemical characteristics of VEGF-siRNA/CRS}

Faraday-Tyndall effect is a special feature of nanoparticles. This phenomenon reflects the nanostructures of CRS solution. VEGF-siRNA/CRS was prepared at different concentrations in sample tubes, and Faraday-Tyndall effect was observed under laser beam at $650 \mathrm{~nm}$.

DEPC water was used as NC (solution A; Figure 2A). Solution B (25\% CRS) in Figure 2B presented obvious Faraday-Tyndall effect. As concentration went higher, Faraday-Tyndall effect could be observed in solution C (50\% CRS) of Figure 2C, solution D ( $75 \%$ CRS) of Figure 2D and solution E (100\% CRS) of Figure 2E. The nano-property of CRS in ultrapure water was also characterized; the size, distribution and $\zeta$ potential were measured by Malvern Zetasizer.

As shown in Figure 3A, the size of the siRNA-CRS decreased from $89.2 \%$ to $36.8 \%$ after incubating with siRNA ("Preparation of gel electrophoresis of VEGF-siRNA/CRS" section). The $\zeta$ potential of all test groups was changed from negative to positive (Figure 3B), which indicated that VEGF-siRNA/CRS became more stable compared to CRS after binding with siRNA. The structure of the carrier was tighter, and the particle size was reduced. With different CRS concentrations, the mean size of VEGF-siRNA/CRS nanoparticle was calculated between $76.2 \pm 0.8 \mathrm{~nm}$ and $121.4 \pm 0.3 \mathrm{~nm}$ (Figure $3 \mathrm{~A}$ ), while the $\zeta$ potential increased from $0 \mathrm{mV}$ to $7.69 \pm 4.47 \mathrm{mV}$ (Figure 3B). These results again confirmed the successful synthesis of siRNA/CRS.
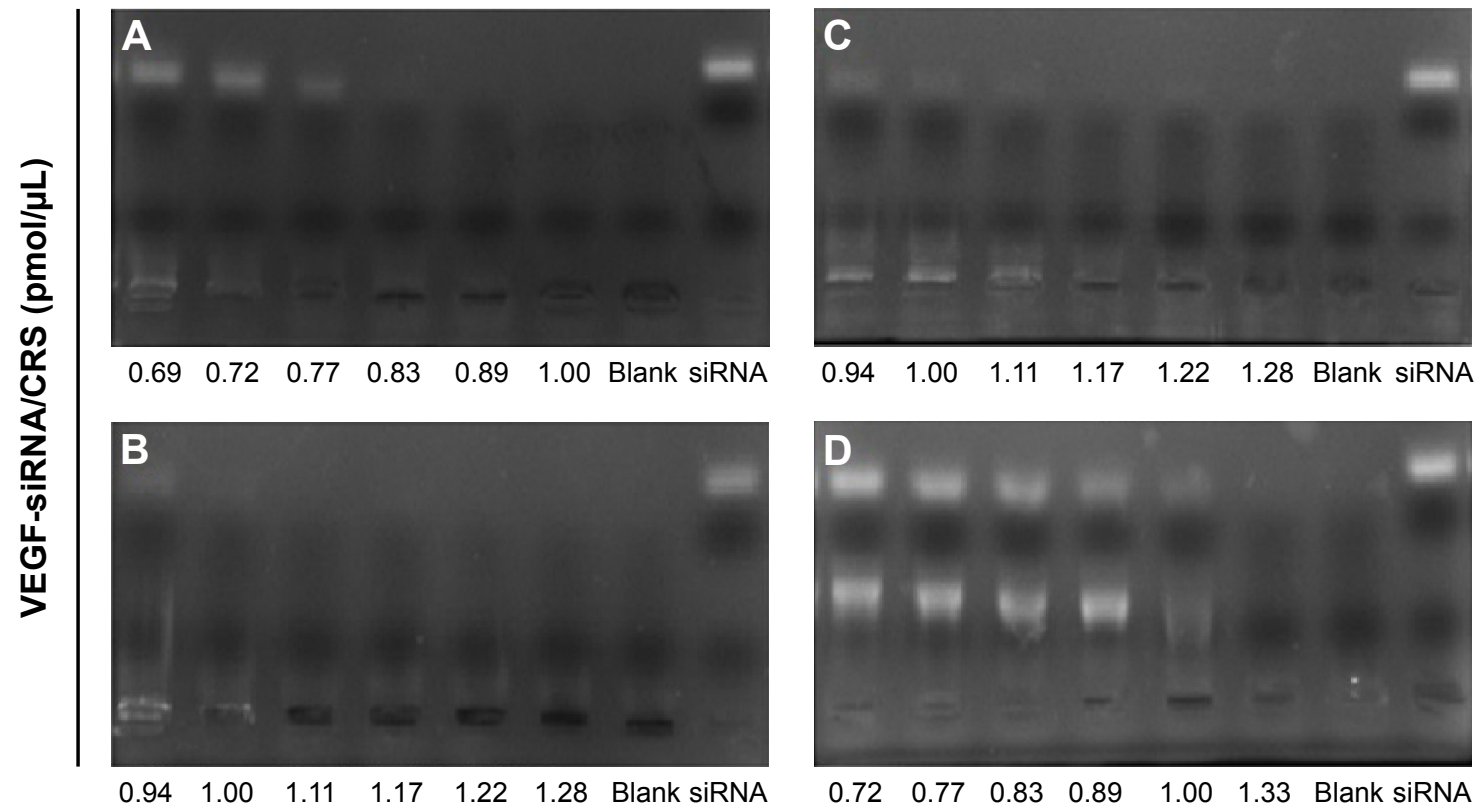

Figure I The agarose gel electrophoresis of VEGF-siRNA and CRS with different concentrations.

Notes: (A) 100\% CRS, (B) 75\% CRS, (C) 50\% CRS and (D) 25\% CRS ( $n=3$ ).

Abbreviation: siRNA, small interfering RNA. 


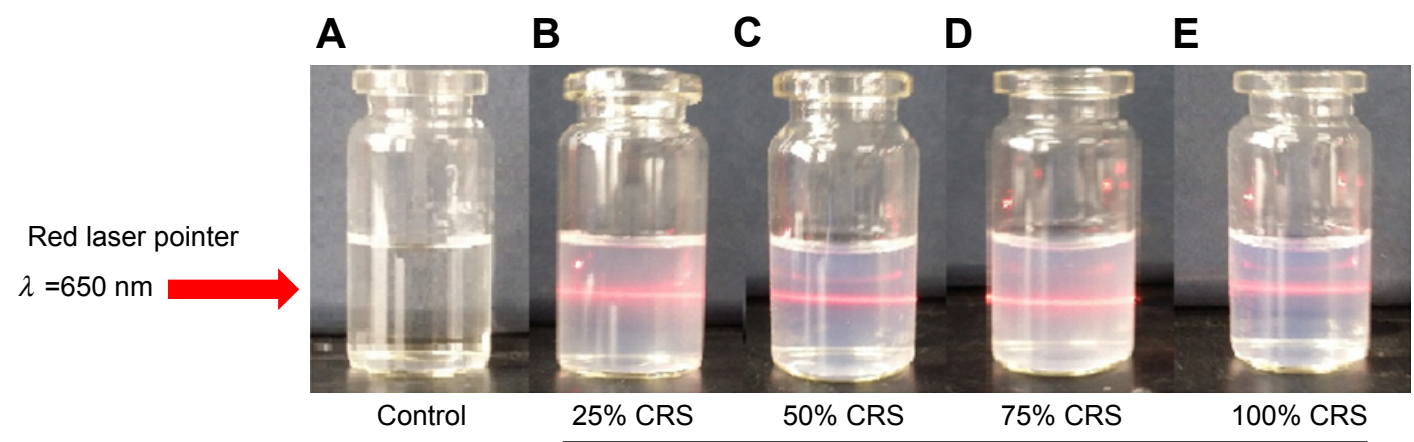

Concentration $100 \mathrm{nM}$
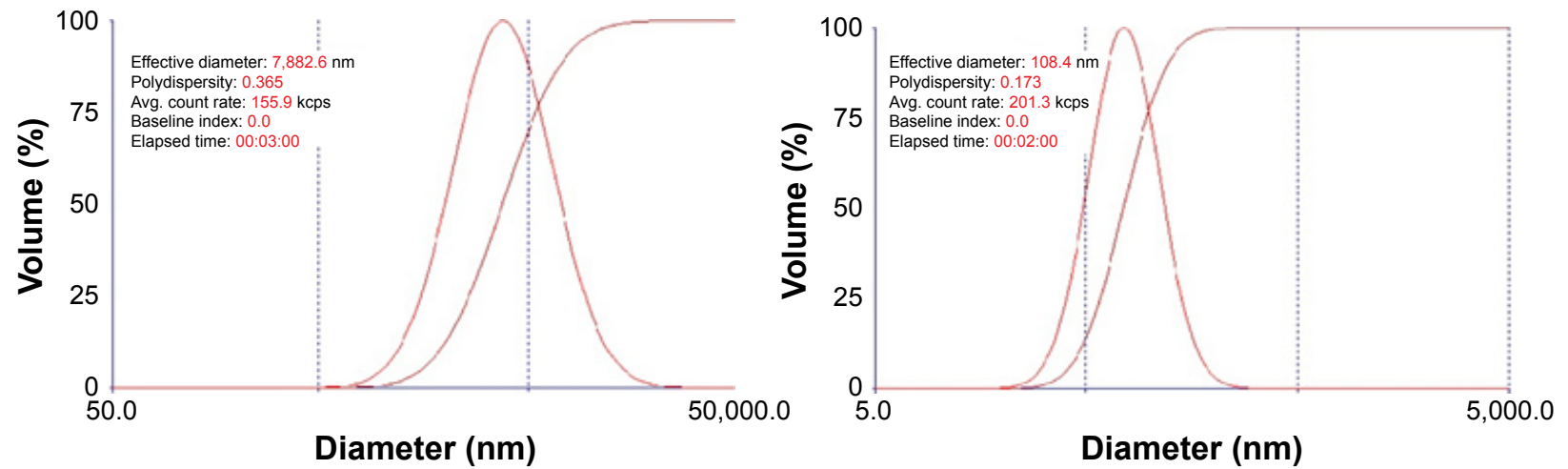

Figure 2 Faraday-Tyndall effect of control and CRS (25\%, 50\%, 75\%, 100\%).

Note: A, B, C, D and E are control, $25 \%, 50 \%, 75 \%$ and $100 \%$ of CRS, respectively.

In DEPC-diluted solution, morphology of VEGF-siRNA/ CRS was studied.

The TEM and SEM images of nanostructure of VEGFsiRNA/CRS are shown in Figure 4. From these images, it was observed that each VEGF-siRNA/CRS formed a nanosphere, $100-200 \mathrm{~nm}$ in diameter. The gradually dissolved nanosphere could contribute to the well-distributed and long-sustaining release ability of the complex; the results of the release experiment are given in the "In vitro VEGF-siRNA and CRS release" section.

\section{Confocal image of siRNA transfection}

Nucleus dye (red) was used as a fluorescence probe to highlight the nucleus of the HeLa cells. Cy3 dye (green) was used
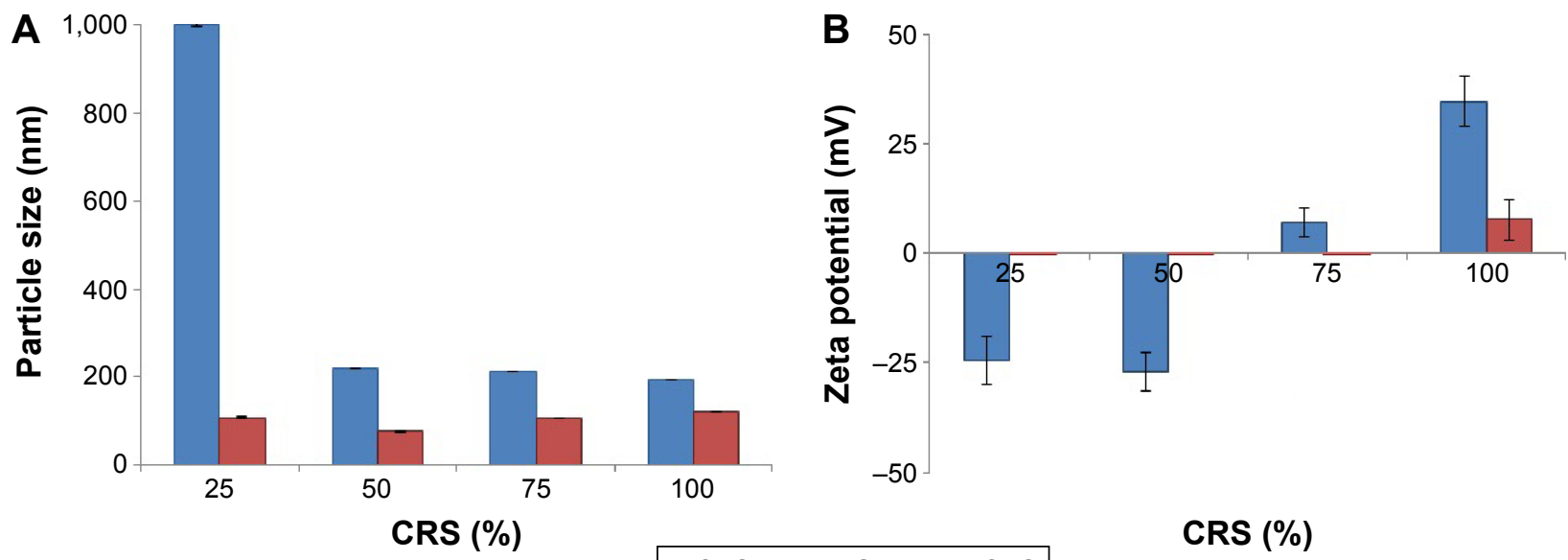

CRS (\%)

$\square$ CRS $\square$ VEGF-siRNA/CRS

Figure 3 Nano-properties of CRS and VEGF-siRNA/CRS.

Notes: (A) Particle size and (B) $\zeta$ potential of various CRS concentrations $(n=3)$.

Abbreviation: siRNA, small interfering RNA. 

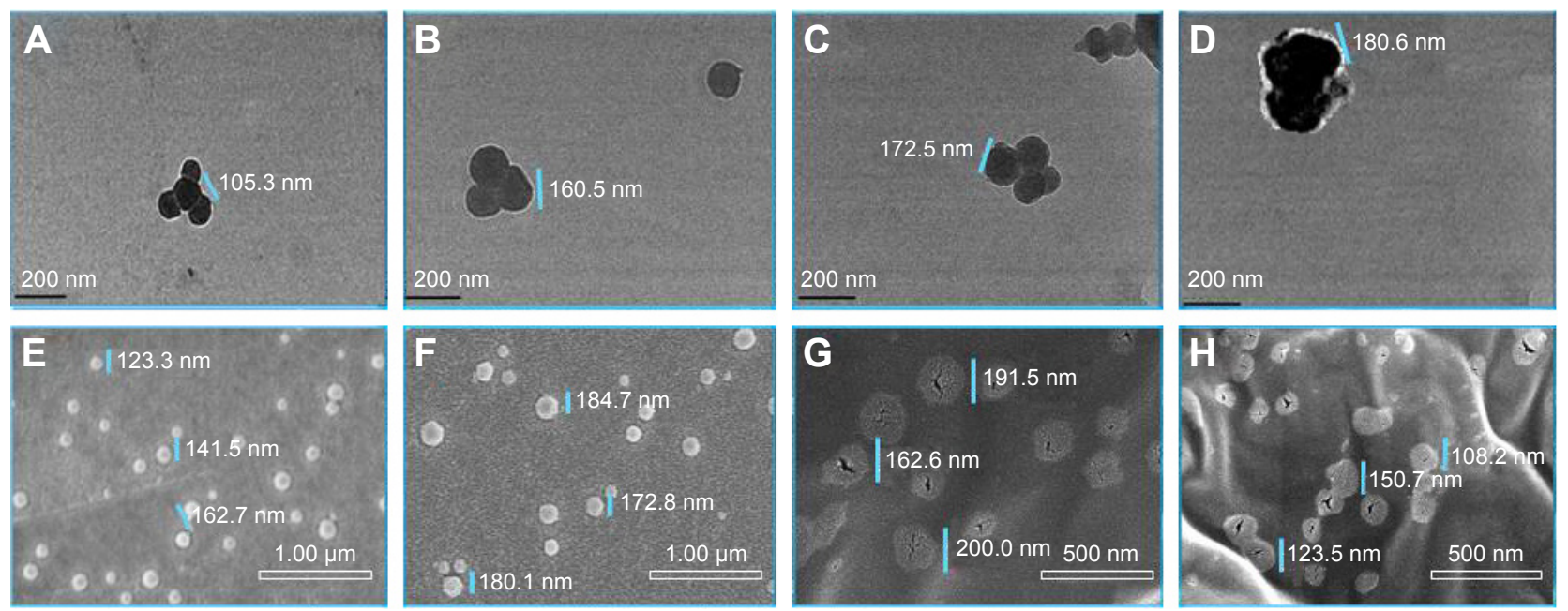

Figure 4 TEM (A-D) and SEM (E-H) images of VEGF-siRNA/CRS

Abbreviations: TEM, transmission electron microscopy; SEM, scanning electron microscopy; siRNA, small interfering RNA.

to test VEGF-siRNA (green)/CRS transfected into cytoplasm. HeLa cells were transfected for $2 \mathrm{~h}$ and $4 \mathrm{~h}$. The results were observed under the confocal microscope and are shown in Figure 5. The red cell nucleus was surrounded by green VEGF-siRNA, which indicated the efficient absorption and transfection of VEGF-siRNA to HeLa cells.

In Figure 5, compared with negative and positive controls, VEGF-siRNA enwrapped with $100 \%$ CRS distributed tightly around cell membrane after $2 \mathrm{~h}$ incubation, and it transfected into cells generously at $4 \mathrm{~h}$. However, in $25 \%, 50 \%$ and $75 \%$ groups, the transfection of siRNA could barely be observed. The results showed that VEGF-siRNA was co-localized with CRS in cells after $2 \mathrm{~h}$ and $4 \mathrm{~h}$ incubation. This indicated that siRNA was well loaded by CRS. The results suggested that VEGF-siRNA/CRS could enter the cytoplasm, and its gene-silencing effect is given in the "Enzyme-linked immunosorbent assay" section.

\section{In vitro VEGF-siRNA and CRS release}

In vitro release of VEGF-siRNA and CRS from VEGF-siRNA/ CRS was measured by UV spectrophotometer and fluoro spectrophotometer. The catabolites of VEGF-siRNA and CRS were plotted using time against release percentage.

The results are shown in Figure 6. After a burst release from $1 \mathrm{~h}$ to $12 \mathrm{~h}$, a constant release of $57.66 \%$ of totally conjugated CRS was observed within $50 \mathrm{~h}$. During the slow releasing period, CRS released and reached $62.63 \%$, meanwhile siRNA released more quickly and reached $82.50 \%$ at $48 \mathrm{~h}$. There was no significant difference between the CRS group and the untreated CRS group, indicating that the CRS and VEGF-siRNA could be slowly released from VEGF-siRNA/CRS.

\section{Cell viability study}

Tumor angiogenesis was essential in tumor cell growth, and it could be efficiently inhibited by downregulating the VEGF gene expression. In this research, in vitro tumor growth inhibitory activity of different concentrations of VEGF-siRNA/CRS was studied using CCK-8 assay against HeLa cells.

The results are shown in Figure 7. At $125 \mathrm{nM}$, cell viability of NC, positive control and VEGF-siRNA of 25\%, $50 \%, 75 \%$ and $100 \%$ was $90.32 \%, 57.66 \%, 30.15 \%, 28.24 \%$, $5.86 \%$ and $6.74 \%$, respectively. Cell viability of all the test candidate's group was $<60 \%$, indicating that the inhibitory activity of test candidates was significantly higher than the positive control and $\mathrm{NC}(P<0.01)$. Compared with $\mathrm{NC}$ and $\mathrm{NC} / \mathrm{CRS}$, both CRS and VEGF-siRNA/CRS groups showed higher inhibition $(P>0.05)$, while the VEGF-siRNA/CRS group $(6.74 \%$ at $125 \mathrm{nM})$ had more inhibitory ability than the CRS group $(60.26 \%$ at $125 \mathrm{nM} ; P<0.01)$. The half maximal inhibitory concentration value of VEGF-siRNA/ CRS $(100 \%)$ was calculated as $63.50 \mathrm{nM}$. These results were further clarifications of the successful linking and transfection of VEGF-siRNA/CRS. Moreover, the CRS group exhibited low cytotoxicity, which was considered to be a good property of the carrier.

\section{Enzyme-linked immunosorbent assay}

To investigate the gene-silencing efficiency of VEGFsiRNA/CRS, the expression of VEGF protein in HeLa cells was evaluated by ELISA. The signal of VEGF protein was amplified, which could ease the observation and gave evidence of the gene-silencing effect. 


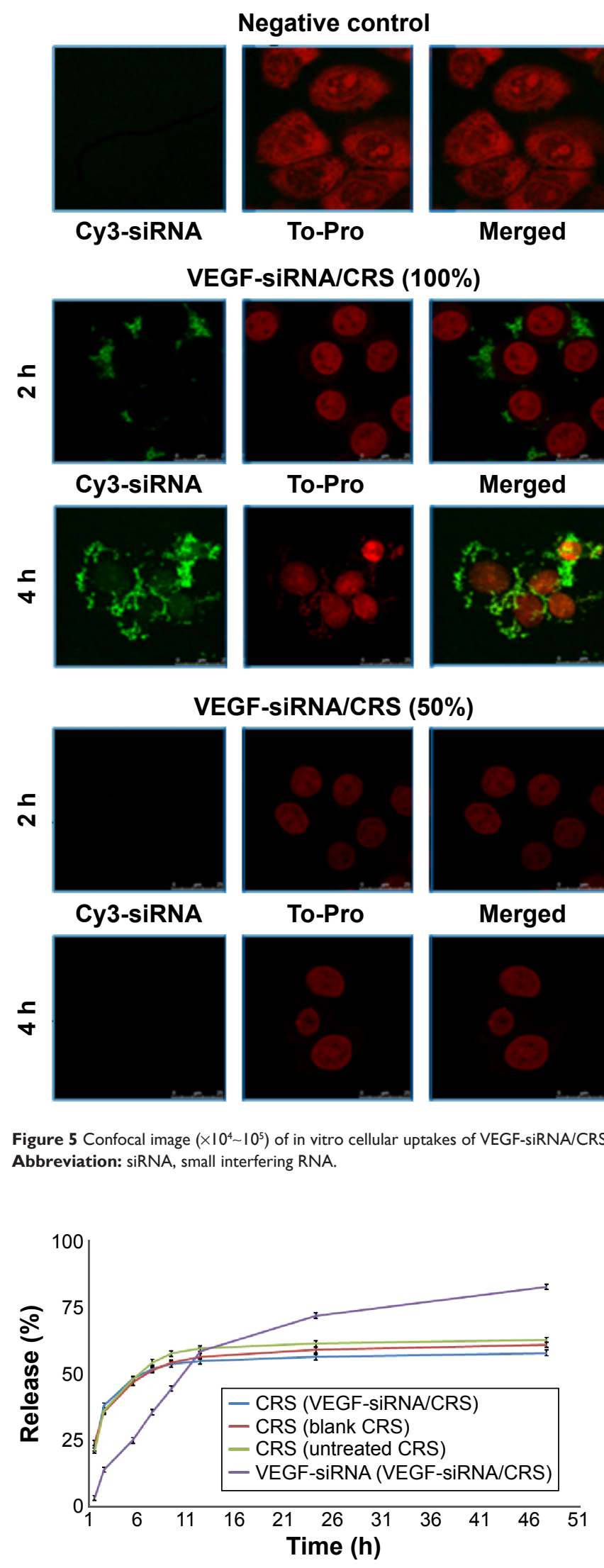

Figure 5 Confocal image $\left(\times 10^{4} \sim 10^{5}\right)$ of in vitro cellular uptakes of VEGF-siRNA/CRS at $2 \mathrm{~h}$ and $4 \mathrm{~h}$. Abbreviation: siRNA, small interfering RNA.
Figure 6 Release of VEGF-siRNA and CRS from VEGF-siRNA/CRS. Note: Data are presented as mean \pm SD $(n=3)$.

Abbreviations: siRNA, small interfering RNA; SD, standard deviation.

\section{Positive control}

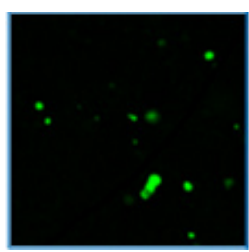

Cy3-siRNA

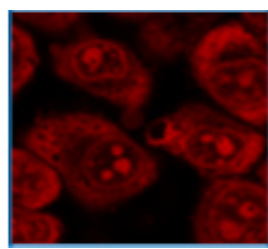

To-Pro

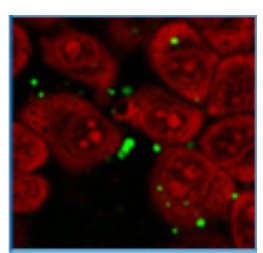

Merged
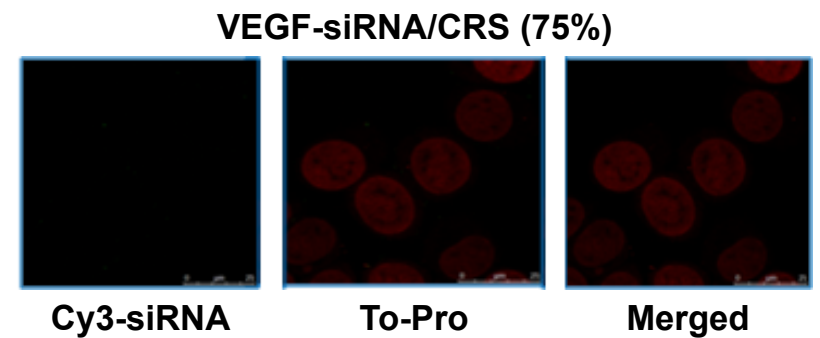

To-Pro

Merged
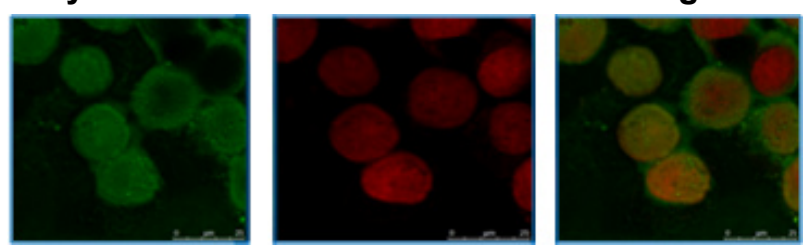

VEGF-SIRNA/CRS (25\%)
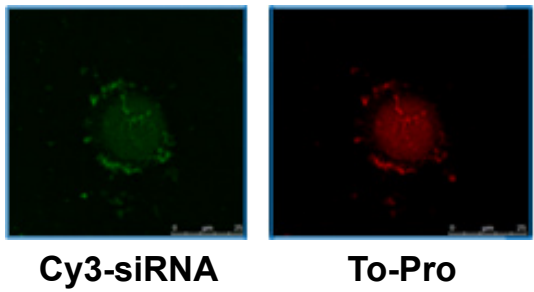

To-Pro
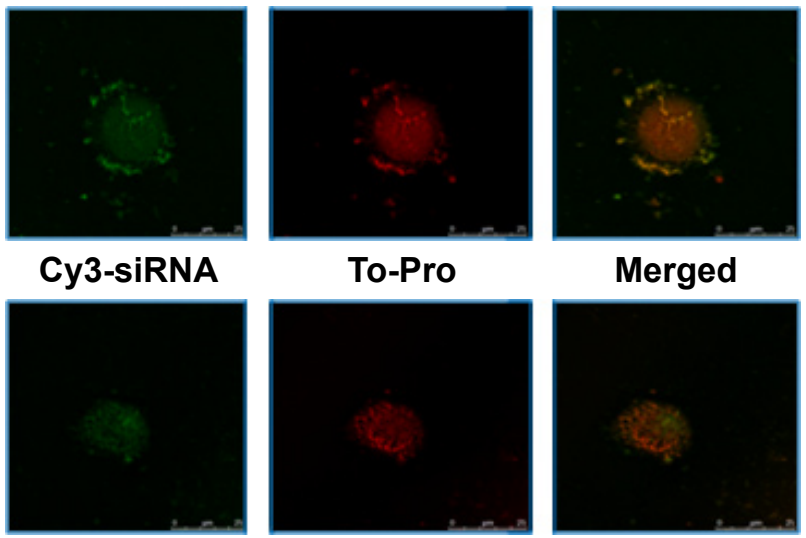

Merged

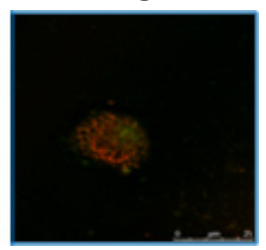

As shown in Figure 8, the highest protein inhibitory ability could be achieved at $125 \mathrm{nM}$ of VEGF-siRNA/CRS. The lowest VEGF secretion rate (14.83\%) was recorded at $125 \mathrm{nM}$ from the VEGF-siRNA/CRS group compared to the NC $(102.57 \%)$ and NC/CRS $(97.76 \%)$ groups $(P<0.01)$. Moreover, the VEGF-siRNA/CRS group had obvious growth inhibition activity $(44.22 \%, 23.00 \%, 14.83 \%)$ at $75 \mathrm{nM}$, $100 \mathrm{nM}$ and $125 \mathrm{nM}$, respectively, compared to the positive control (VEGF-siRNA/Lipofectamine ${ }^{\mathrm{TM}}$ 2000, 24.62\%, $P<0.05$ ). Both $100 \mathrm{nM}$ and $125 \mathrm{nM}$ groups of VEGF-siRNA/ CRS had shown a downregulating effect, and the silencing of VEGF gene could be inferred. 


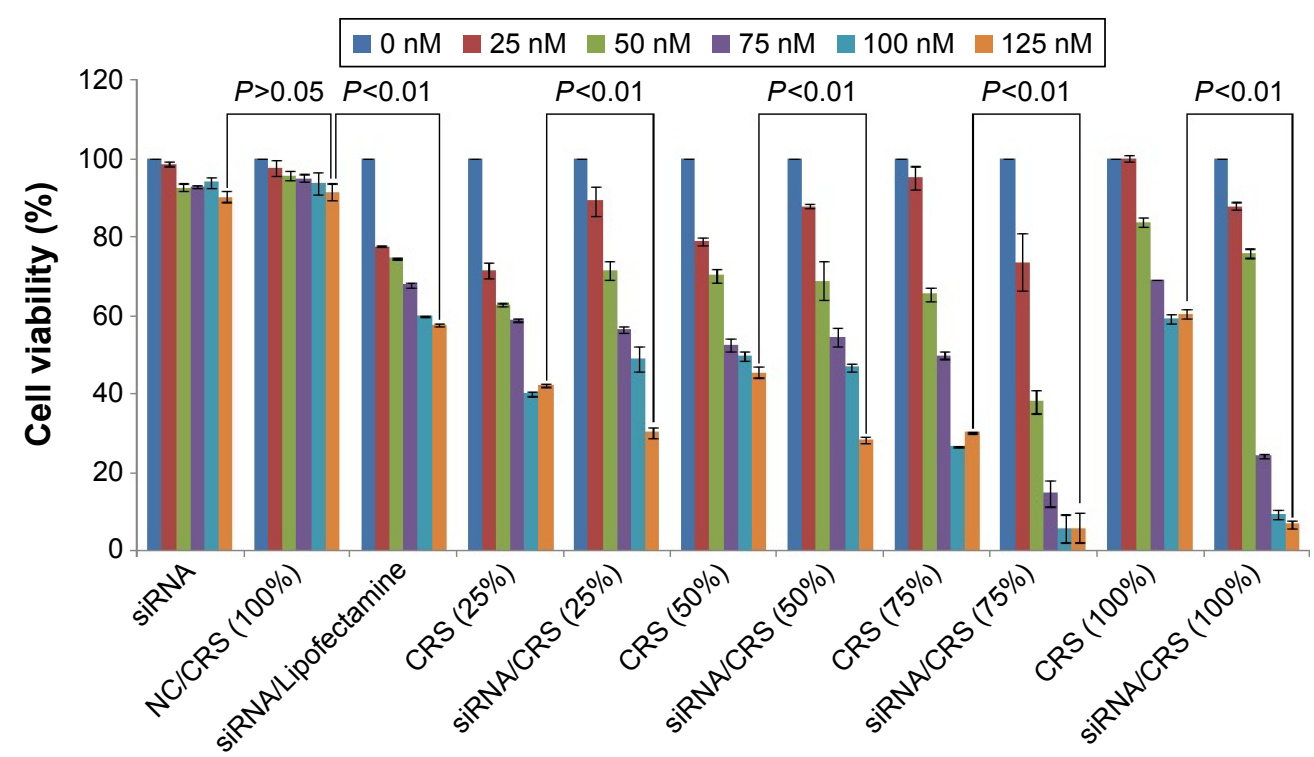

Figure 7 In vitro inhibition of HeLa cells treated by VEGF-siRNA/CRS ( $n=3)$.

Abbreviations: NC, negative control; siRNA, small interfering RNA.

\section{Real-time PCR}

The expression of VEGF mRNA was proved by RT-PCR. Total RNA was extracted from HeLa cells, reverse transcripted into cDNA and amplified to mRNA for tests. The downregulation of mRNA reflected the inhibition effects caused by VEGF-siRNA.

The results shown in Figure 9 indicated that there was a reduction in VEGF mRNA transcription when compared to controls. Decreased expression of mRNA could be effected by test groups ( $75 \mathrm{nM}, 100 \mathrm{nM}$ and $125 \mathrm{nM}$ VEGF-siRNA/CRS) gradually, and the expression rate of mRNA was at $41.39 \%, 28.36 \%$ and $27.64 \%$ respectively, compared with the blank control.
The inconstant decreasing results reflected that the gene silencing could reach the higher limitation at concentration of $100 \mathrm{nM}$, and the continuously increased concentration of VEGF-siRNA/CRS caused no further effect on mRNA expression. The results suggest that the VEGF-siRNA could transfer into HeLa cells and inhibit the expression of VEGFmRNA in vitro.

\section{Successful formation of xenograft model and distribution in vivo}

The experimental animal was observed by MRI, and the tumor in the right armpit was detected to confirm the formation of

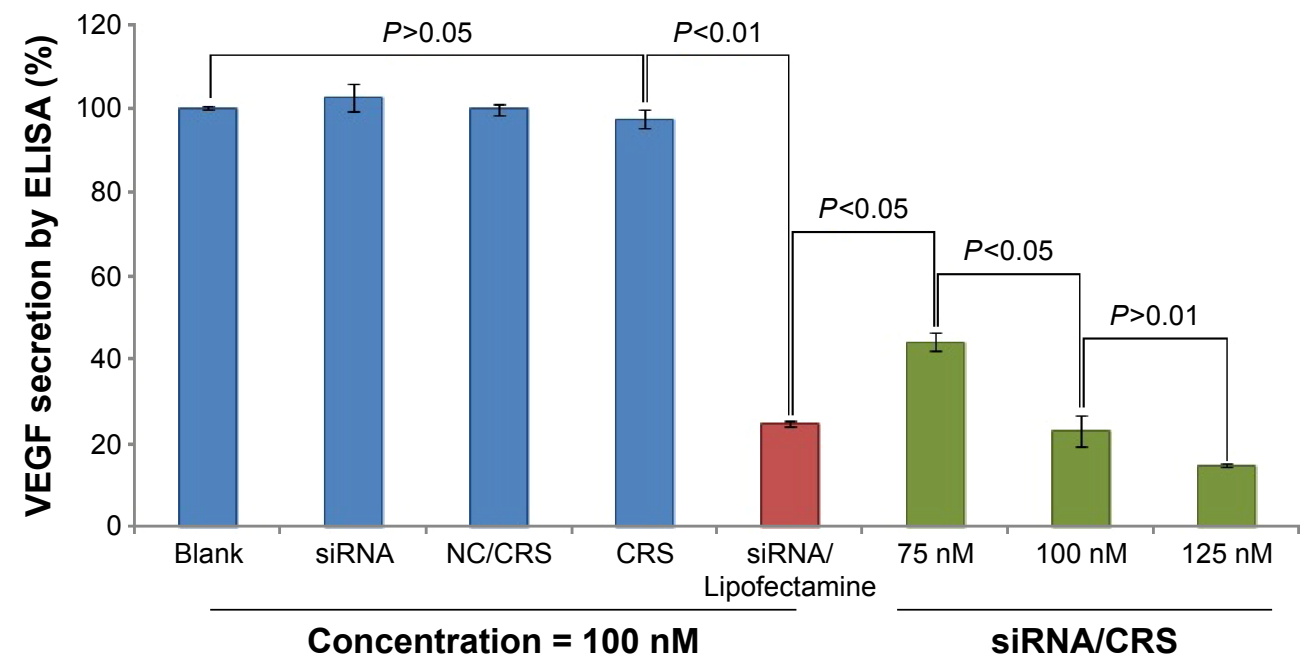

Figure 8 ELISA results for VEGF protein expression of HeLa cells treated with VEGF-siRNA/CRS.

Note: Data are presented as mean \pm SD $(n=3)$.

Abbreviations: NC, negative control; siRNA, small interfering RNA; ELISA, enzyme-linked immunosorbent assay; SD, standard deviation. 


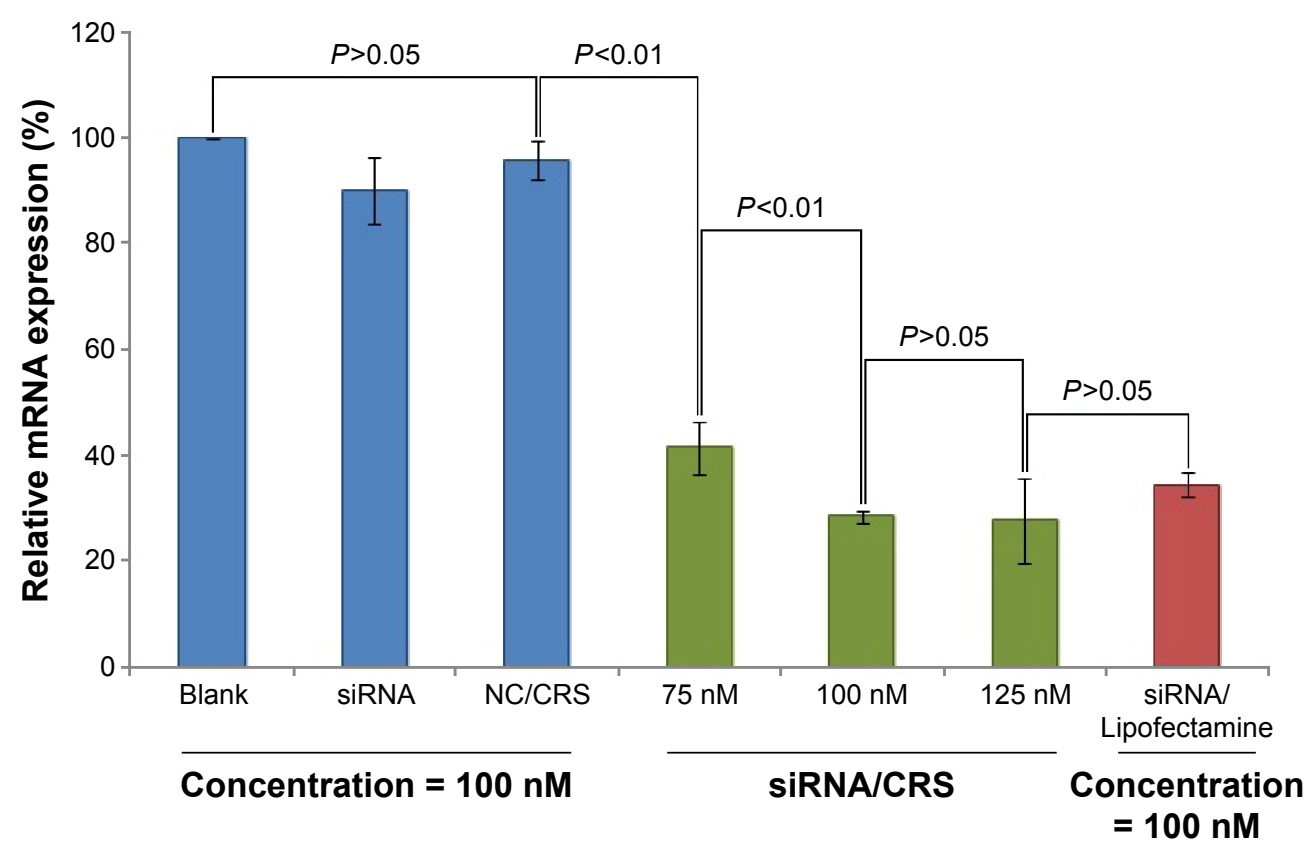

Figure 9 Gene-silencing efficiency of VEGF-siRNA/CRS on HeLa cells.

Note: Data are presented as mean \pm SD $(n=3)$.

Abbreviations: NC, negative control; siRNA, small interfering RNA; SD, standard deviation.

the xenograft model. Images of MRI coronal sections are shown in Figure 10, in which the tumor is indicated in the blue circle.

To investigate the distribution of the injected carrier, images (Figure 11) were taken at set times. There was no signal detected at 0 min. After 15 min, compared with B (only $\mathrm{Cy} 3$ injected), the distribution of Cy3-CRS was observed in brain, tumor, penis and limbs in group A. This distribution lasted for $60 \mathrm{~min}$, and after $1 \mathrm{~h}$, the carrier started to metabolize and the signal was observed in the liver. Over $120 \mathrm{~min}$, the carrier had been eliminated from the tumor area and the signal was observed in the liver and kidney, which indicated that the clearance time for VEGF-siRNA was approximately within $2 \mathrm{~h}$, and then, it could be cleared through the kidney. The results showed consistency with the related literature. ${ }^{28}$

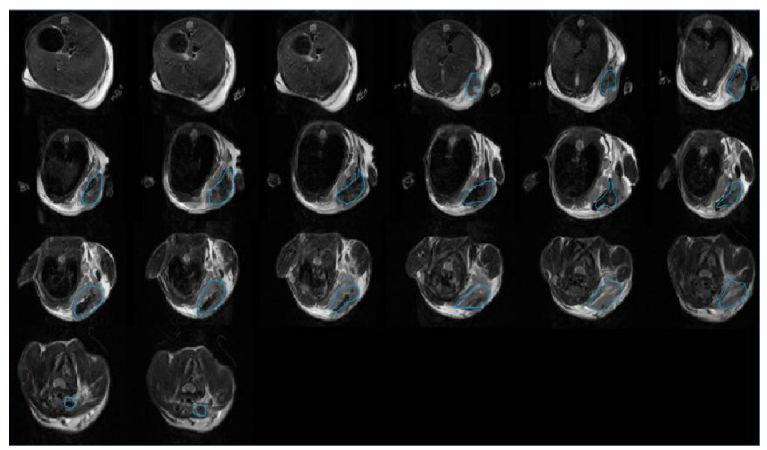

Figure 10 The coronal sections of the tumor from the right armpit of mice. Note: The tissue of the right armpit of each mouse is shown in gray, and the tumors are shown with the blue circles.

\section{Tumor growth inhibition}

The inhibitory effect of VEGF-siRNA/CRS on tumor growth was evaluated using S180 mice. Tumor weight was used to identify the tumor inhibitory activity.

In Figure 12, the tumor weight of the normal saline group was used as $\mathrm{NC}$ and that of the DOX group was used as positive control. The comparison of two controls indicated the successful implantation of tumor. Tumor weights of the NC group $(3.23 \pm 0.61 \mathrm{~g})$ and naked siRNA group $(2.79 \pm 0.49 \mathrm{~g})$ were significantly higher than that of VEGF-siRNA/CRS $(1.58 \pm 0.38 \mathrm{~g} ; P<0.01)$. VEGF-siRNA/CRS showed antitumor activity and did not have a significant difference compared with the positive control $(1.53 \pm 0.32 \mathrm{~g} ; P>0.05)$ in vivo, considering tumor weight. Moreover, the CRS group (35.81\%) exhibited inhibitory activity against the siRNA $(13.50 \%)$ but lower than that of VEGF-siRNA/CRS (51.21\%), which might be caused by the silencing effects of VEGF gene.

\section{Conclusion}

In this study, we successfully prepared 1-methyl- $\beta$-caboline3-RGDS (CRS) and demonstrated that it was a safe and effective carrier for siRNA delivery. The RGDS was conjugated with 1-methyl- $\beta$-caboline and then absorbed with siRNA by electrostatic interactions and van der Waals force to form siRNA/CRS nanoparticles. The results showed that the carrier could efficiently deliver siRNA into HeLa cells, induce significant gene-silencing effects, and regulate the related protein expression in cellular levels. Meanwhile, 

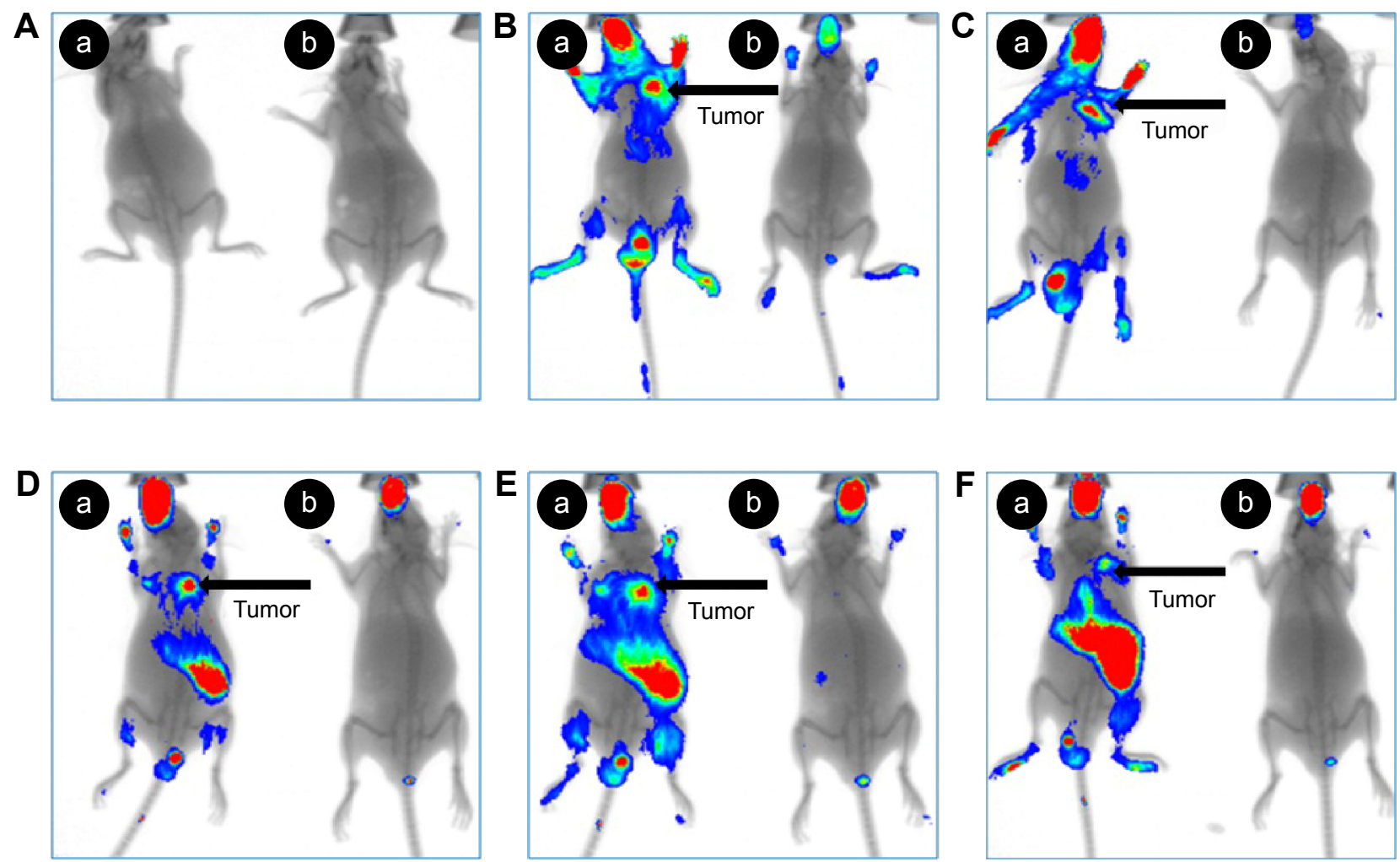

Figure II Imaging of mice from animal fluorescence system.

Notes: (A) 0 min; (B) 15 min; (C) $30 \mathrm{~min}$; (D) $60 \mathrm{~min}$; (E) $120 \mathrm{~min}$; (F) $240 \mathrm{~min}$. (a) Cy3-CRS injected and (b) Cy3 injected.
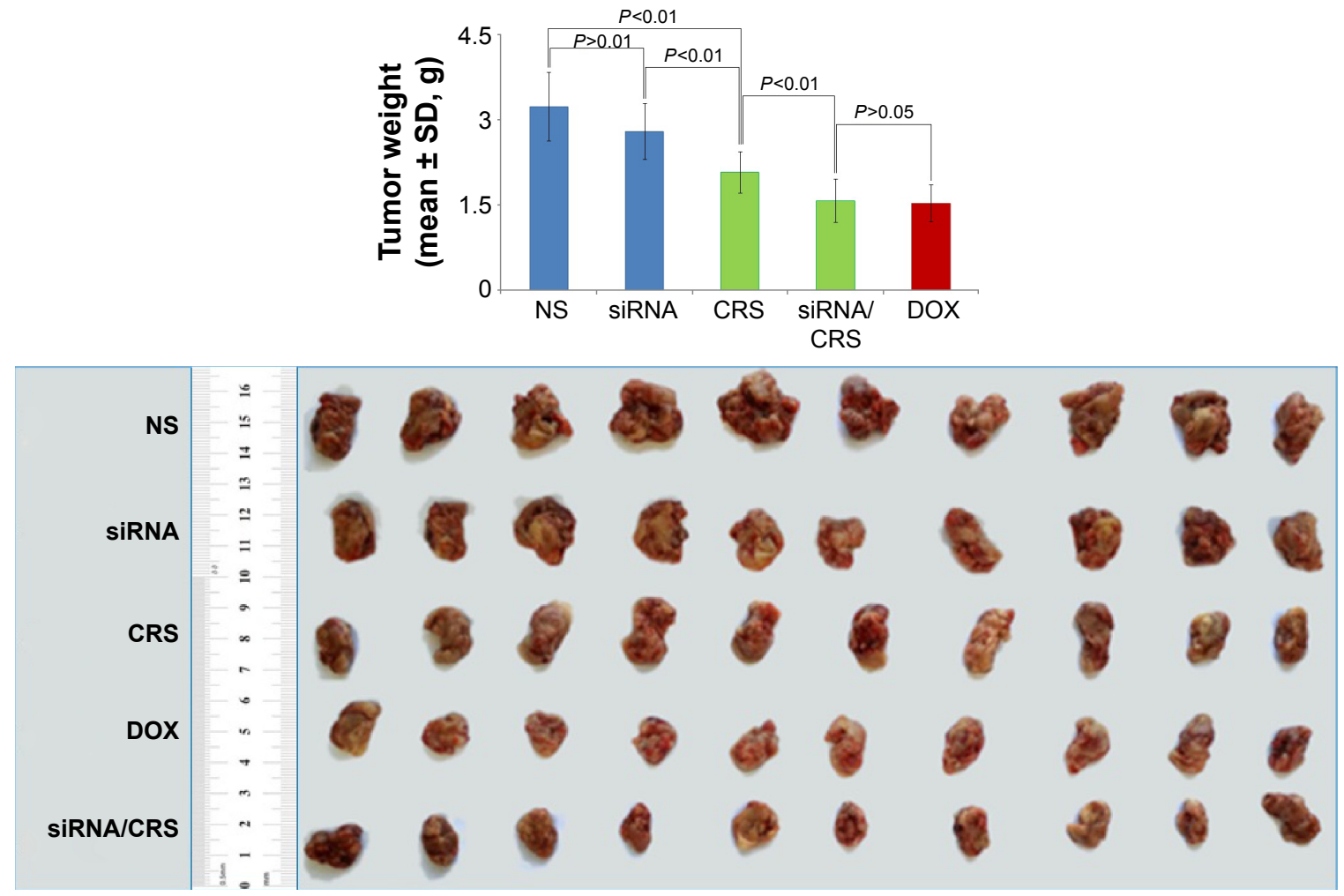

Figure 12 In vivo antitumor effect of VEGF-siRNA/CRS.

Note: Data are presented as mean \pm SD $(n=10)$.

Abbreviations: DOX, doxorubicin; NS, normal saline; SD, standard deviation; siRNA, small interfering RNA. 
RGDS peptide targeted tumor cells and caused a concentrated distribution of nanocarriers around the tumor area.

In summary, a new siRNA carrier was synthesized and generated with 1-methyl- $\beta$-caboline-3-carboxylic acid and RGDS peptide, and the synthesis procedure is reported here. The results showed that VEGF-siRNA/CRS was not only able to form a stable nanocarrier but also exhibited the VEGF gene-silencing effect and caused inhibitory activity of tumor growth in vivo. These findings suggested that VEGF-siRNA/ CRS should be used as a low-toxic and highly-effective gene carrier in the delivery system.

\section{Acknowledgments}

This work was supported by the National Natural Science Foundation (81502688), the Basic-Clinical Key Research Grant (16JL72) from Capital Medical University, the Importation and Development of High-Caliber Talents Project of Beijing Municipal Institutions (2013-2015), Natural Science Foundation of Capital Medical University (2015ZR14), China's 55th Postdoctoral Scientific Research Funds (2014M550768) and the Principal Fund of Capital Medical University (16GLY09). The authors gratefully acknowledge the support from Beijing Area Major Laboratory of Peptide and Small Molecular Drugs, Engineering Research Center of Endogenous Prophylactic of Ministry of Education of China, and Beijing Laboratory of Biomedical Materials.

\section{Disclosure}

The authors report no conflicts of interest in this work.

\section{References}

1. Bumcrot D, Manoharan M, Koteliansky V, Sah DW. RNAi therapeutics: a potential new class of pharmaceutical drugs. Nat Chem Biol. 2006;2(12): 711-719.

2. Hu CM, Zhang L. Nanoparticle-based combination therapy toward overcoming drug resistance in cancer. Biochem Pharmacol. 2012;83(8): 1104-1111.

3. Aliabadi HM, Landry B, Sun C, Tang T, Uludag H. Supramolecular assemblies in functional siRNA delivery: where do we stand? Biomaterials. 2012;33(8):2546-2569.

4. Lorenzer C, Dirin M, Winkler AM, Baumann V, Winkler J. Going beyond the liver: progress and challenges of targeted delivery of siRNA therapeutics. J Control Release. 2015;203:1-15.

5. Geusens B, Sanders N, Prow T, Van Gele M, Lambert J. Cutaneous short-interfering RNA therapy. Expert Opin Drug Deliv. 2009;6(12): 1333-1349.

6. Wang Z, Zou H, Wang Z, Wu J, Xia Z, Feng M. Highly stable polyglutamate derivatives/siRNA polyplex efficiently down-relegate survivin expression and augment the efficacy of cisplatin. Int J Pharm. 2016; 505(1-2):24-34.

7. Ginn SL, Alexander IE, Edelstein ML, Abedi MR, Wixon J. Gene therapy clinical trials worldwide to 2012 - an update. J Gene Med. 2013;15(2): 65-77.

8. Chen J, Xie J. Progress on RNAi-based molecular medicines. Int J Nanomedicine. 2012;7:3971-3980.
9. Kullberg M, McCarthy R, Anchordoquy TJ. Systemic tumor-specific gene delivery. J Control Release. 2013;172(3):730-736.

10. Zheng M, Yang Y, Zhao M, et al. A class of novel N-isoquinoline-3carbonyl-L-amino acid benzylesters: synthesis, anti-tumor evaluation and 3D QSAR analysis. Eur J Med Chem. 2011;46(5):1672-1681.

11. Yue P, Wang C, Dan J, Liu W, Wu Z, Yang M. The importance of solidification stress on the redispersibility of solid nanocrystals loaded with harmine. Int J Pharm. 2015;480(1-2):107-115.

12. Wu J, Li C, Zhao M, Wang W, Wang Y, Peng S. A class of novel carboline intercalators: their synthesis, in vitro anti-proliferation, in vivo antitumor action, and 3D QSAR analysis. Bioorg Med Chem. 2010;18(17): $6220-6229$

13. Xu Y, Wang Y, Zhao M, et al. Lead detoxification activities and ADMET hepatotoxicities of a class of novel 5-(1-carbonyl-L-aminoacid)-2,2-dimethyl-[1,3]dithiolane-4-carboxylic acids. Bioorg Med Chem Lett. 2011;21(6):1754-1757.

14. Desmet E, Bracke S, Forier K, et al. An elastic liposomal formulation for RNAi-based topical treatment of skin disorders: proof-of-concept in the treatment of psoriasis. Int J Pharm. 2016;500(1-2):268-274.

15. Mouguelar VS, Cabada MO, Coux G. The integrin-binding motif RGDS induces protein tyrosine phosphorylation without activation in Bufo arenarum (Amphibia) oocytes. Reproduction. 2011;141(5):581-593.

16. Tejeda-Montes E, Smith KH, Rebollo E, et al. Bioactive membranes for bone regeneration applications: effect of physical and biomolecular signals on mesenchymal stem cell behavior. Acta Biomater. 2014;10(1): 134-141.

17. Cavalcanti-Adam EA, Volberg T, Micoulet A, Kessler H, Geiger B, Spatz JP. Cell spreading and focal adhesion dynamics are regulated by spacing of integrin ligands. Biophys J. 2007;92(8):2964-2974.

18. Gomes-da-Silva LC, Santos AO, Bimbo LM, et al. Toward a siRNAcontaining nanoparticle targeted to breast cancer cells and the tumor microenvironment. Int J Pharm. 2012;434(1-2):9-19.

19. Li C, Zhang X, Zhao M, et al. A class of novel N-(1-methyl-betacarboline-3-carbonyl)- $\mathrm{N}^{\prime}$-(aminoacid-acyl)-hydrazines: aromatization leaded design, synthesis, in vitro anti-platelet aggregation/in vivo antithrombotic evaluation and 3D QSAR analysis. Eur J Med Chem. 2011; 46(11):5598-5608.

20. Liu J, Zhang X, Zhao M, Peng S. Synthesis, evaluation and 3D QSAR analysis of novel estradiol-RGD octapeptide conjugates with oral antiosteoporosis activity. Eur J Med Chem. 2009;44(4):1689-1704.

21. Zhao M, Liu J, Zhang X, Peng L, Li C, Peng S. 3D QSAR of novel estrogen-RGD peptide conjugates: getting insight into structural dependence of anti-osteoporosis activity and side effect of estrogen in ERT. Bioorg Med Chem. 2009;17(10):3680-3689.

22. Bailey AL, Sullivan SM. Efficient encapsulation of DNA plasmids in small neutral liposomes induced by ethanol and calcium. Biochim Biophys Acta. 2000;1468(1-2):239-252.

23. Lv H, Zhang S, Wang B, Cui S, Yan J. Toxicity of cationic lipids and cationic polymers in gene delivery. J Control Release. 2006;114(1): $100-109$.

24. Tamaru M, Akita H, Kajimoto K, Sato Y, Hatakeyama H, Harashima H. An apolipoprotein E modified liposomal nanoparticle: ligand dependent efficiency as a siRNA delivery carrier for mouse-derived brain endothelial cells. Int J Pharm. 2014;465(1-2):77-82.

25. Varkouhi AK, Scholte M, Storm G, Haisma HJ. Endosomal escape pathways for delivery of biologicals. J Control Release. 2011;151(3): 220-228.

26. Schafer J, Hobel S, Bakowsky U, Aigner A. Liposome-polyethylenimine complexes for enhanced DNA and siRNA delivery. Biomaterials. 2010;31(26):6892-6900.

27. Koynova R, Tenchov B. Enhancing nucleic acid delivery, insights from the cationic phospholipid carriers. Curr Pharm Biotechnol. 2014;15(9): 806-813.

28. Ballou B, Fisher GW, Deng JS, Hakala TR, Srivastava M, Farkas DL. Cyanine fluorochrome-labeled antibodies in vivo: assessment of tumor imaging using Cy3, Cy5, Cy5.5, and Cy7. Cancer Detect Prev. 1998; 22(3):251-257. 


\section{Publish your work in this journal}

Drug Design, Development and Therapy is an international, peerreviewed open-access journal that spans the spectrum of drug design and development through to clinical applications. Clinical outcomes, patient safety, and programs for the development and effective, safe, and sustained use of medicines are the features of the journal, which has also been accepted for indexing on PubMed Central. The manuscript management system is completely online and includes a very quick and fair peer-review system, which is all easy to use. Visit http://www.dovepress.com/testimonials.php to read real quotes from published authors.

Submit your manuscript here: http://www.dovepress.com/drug-design-development-and-therapy-journal 